\title{
МЕТОДИЧНІ АСПЕКТИ ВИКЛАДАННЯ СТАНДАРТИЗАЦЇ̈ ЛІКАРСЬКИХ ЗАСОБІВ ВІТЧИЗНЯНИМ СТУДЕНТАМ
}

\author{
Н. О. Зарівна, Л. С. Логойда, Д. Б. Коробко \\ ДВНЗ “Тернопільський держсавниймедичний університет імені І. Я. Горбачевського МОЗ Украйни”
METHODOLOGICAL ASPECTS OF TEACHING STANDARDIZATION OF DRUGS FOR UKRAINIAN STUDENTS \\ N. O. Zarivna, L. S. Lohoyda, D. B. Korobko \\ SHEI "Ternopil State Medical University by I. Ya. Horbachevsky of MPH of Ukraine"
}

\begin{abstract}
Викладено основні методичні підходи до викладання дисципліни “Стандартизація лікарських засобів” вітчизняним студентам фармацевтичного факультету, спеціальності “Фармація”.
\end{abstract}

Basic methodical approaches of teaching the course "Standardization of drugs" are presented for ukrainian students of Faculty of Pharmacy, specialty "Pharmacy".

Вступ. Сучасна система вищої освіти ставить завдання неухильно вдосконалювати форми і методи навчання, максимально наближати його організацію до сучасних вимог, дати кожному студенту якісну освіту та можливість бути конкурентоспроможними на ринку праці [1]. Пріоритетним напрямом державної політики у розвитку вищої школи є особиста орієнтація, постійне підвищення якості освіти, оновлення іiі змісту і форм, запровадження освітніх інноваційних технологій, інтеграція вітчизняної освіти до європейського простору [2]. Саме це зумовило необхідність переходу вищої школи до нової кредитно-модульної системи організації процесу навчання, що, у свою чергу, приведе до збагачення інтелектуального та творчого потенціалу студентів. Для цього необхідно раціоналізувати організацію всього навчального процесу, вдосконалити зміст, форми, методи навчальнопізнавальної діяльності студентів вищих навчальних закладів [3].

Основна частина. Навчальна дисципліна "Стандартизація лікарських засобів” належить до циклу дисциплінпрофесійно-орієнтованої підготовки фахівців за напрямком “Фармація”. Оскільки лікарські засоби є продукцією, від якої безпосередньо залежить здоров’я, а часто і життя людини, стандартизація у сфері лікарських засобів має особливо важливе значення i потребує вивчення майбутніми фахівцями. Курс стандартизації лікарських засобів грунтується на знаннях, одержаних при вивченні інших фундаменталь-

() Н. О. Зарівна, Л. С. Логойда, Д. Б. Коробко них дисциплін, зокрема фармацевтичної хімії, та інтегрується $з$ ними. Метою викладання вищевказаної дисципліни є забезпечення майбутнього фахівця фармацевтичної галузі такими спеціальними знаннями, уміннями та практичними навичками, які дадуть йому можливість повноцінно і якісно виконувати свої професійні обов'язки.

Під час викладання “Стандартизації лікарських засобів" закладаються основи вивчення студентами системи стандартизації фармацевтичної продукції [4]. Сучасна система стандартизації фармацевтичної продукції передбачає контроль якості лікарських засобів на стадії виготовлення, зберігання та споживання згідно з існуючими методиками контролю якості (МКЯ) та вимогами в системах GMP/GLP, що забезпечується використанням фізичних, фізикохімічних та хімічних методів дослідження лікарських засобів, теоретичні основи яких були прочитані студентам ще на другому курсі при вивченні дисциплін “Аналітична хімія” i “Фізичні методи аналізу та метрологія" [5].

На практичних заняттях студенти знайомляться 3 основами державної політики і управління у сфері створення, виробництва, контролю якості та реалізації лікарських засобів [4]. Вивчають нормативну документацію (ДФУ, настанови, закони) й іншу нормативну документацію, що регламентує якість фармацевтичних препаратів $[5,6]$. Також набувають навички з реєстрації, сертифікації фармацевтичної продукції, знайомляться та розробляють специфікації на 
лікарські засоби залежно від виду лікарської форми, аналізують готові лікарські засоби (ГЛЗ) на вміст активного фармацевтичного інгредієнта (АФI) та проводять фармако-технологічні випробування [4, 7]. Потреба гарантувати достовірність отриманих результатів кількісного визначення вимагає валідації аналітичних методик і застосування законів математичної статистики, що детально на заняттях студентами вивчаються.

Ефективність і безпечність розроблених ЛЗ підтверджуються на етапах доклінічних і клінічних випробувань, а безпечність виведених на ринок препаратів - досвідом їх клінічного застосування. Об'єктивність даних при цьому забезпечується шляхом дотримання правил GLP i GCP, а також фармаконаглядом, що у свою міру є необхідним вивченням у галузі майбутніх провізорів [7]. Оскільки якість препарату закладається ще на етапі фармацевтичної розробки, студент чітко повинен знати елементи фармацевтичної розробки. Ціль фармацевтичної розробки - розробити якісний препарат і процес його виробництва, щоб постійно випускати продукцію із заданими функціональними характеристиками та конкурентоспроможністю на фармацевтичному ринку [4, 7].

Майбутньому фахівцюу фармацевтичній галузі необхідно навчитися вибирати відповідно до лікарської форми аналітичні методики для контролю якості Л3 і складати специфікації та керуватися в практичній діяльності згідно з МКЯ на ГЛЗ. Детальне і грунтовне ознайомлення з основами дисципліни “Стандартизація лікарських засобів" дає можливість більш повно засвоїти матеріал, що вивчається, реалізувати науково-творчий потенціал студентів, збагачує їх знаннями, які безпосередньо будуть використані в їхній практичній діяльності.

Для освоєння матеріалу згідно з кредитно-модульною системою виділено 12 год лекцій, 36 год практичних занять, 24 год самостійної роботи студентів (СПРС) та 3 практичних навички. Така невелика кількість аудиторних годин вимагає від викладача дуже ретельного підходу до відбору навчального матеріалу та методики його представлення. У кінці семестру передбачено семестровий тестовий іспит. При вивченні даної дисципліни студентам читаються лекції з мультимедійним супроводом, які сприяють всебічному сприйняттю викладеного матеріалу та повнішому його засвоєнню. На лекцію студенти приходять підготовленими, оскільки матеріали підготовки до лекцій розміщені на Web-порталі університету.
Практичні заняття з даної дисципліни проводяться згідно з методикою “єдиного дня”, відповідно до якої навчання студентів становить 5 робочих днів, з яких 1 день призначений для лекцій та 4 дні - для практичних занять. Кожне практичне заняття забезпечене методичними рекомендаціями, матеріалами підготовки до практичного заняття, тестовими завданнями для контролю знань, ситуаційними задачами та методичними вказівками для самостійної роботи студентів.

На практичних заняттях студенти проводять аналіз ГЛЗ, залежно від виду ЛФ (тверді Л3, рідкі ЛЗ, парентеральні Л3, м’які Л3, ЛРС і препарати на ії основі). Проводять ідентифікацію та кількісне визначення АФІ відповідними методами. Для ідентифікації використовують якісні реакції та фізико-хімічні методи аналізу. Кількісне визначення проводять відповідним підхожим методом. Крім підтвердження тотожності та кількісного визначення, студенти також проводять фармако-технологічні випробування згідно з вимогами ДФУ. Розробляють методики ідентифікації та кількісного визначення АФІ, проводять їх валідацію за основними валідаційними характеристиками (лінійність, специфічність, збіжність, робасність тощо). Як підсумок вивченого для кожного студента пропонується розробити проект МКЯ для різних готових лікарських форм як синтетичного, так і рослинного походження. Для узагальнення знань у кінці практичного заняття проводиться тестовий контроль за системою Moodle.

Викладачі постійно працюють над вдосконаленням необхідного навчально-методичного забезпечення дисципліни, прагнуть домогтися засвоєння знань, практичних навичок, сприяють формуванню наукового світогляду, моральних, естетичних та інших якостей особистості, вихованню колективу. Також орієнтуються на потреби студента у певних знаннях, уміннях і навичках з опорою на подальшу самоосвіту, оскільки в навчальному закладі не закінчується формування особистості спеціаліста, воно продовжується все життя впродовж практичної діяльності і безперервного підвищення кваліфікації.

Висновок. Для підготовки студентів фармацевтичного факультету важливе місце займає вивчення дисципліни “Стандартизація лікарських засобів”, інтегруючи закони і методи багатьох наук, ця дисципліна стоїть на сторожі якості лікарських засобів, а значить, і здоров'я народу. Вона дозволяє студентам систематизувати знання та практичні навички й використовувати їх у професійній діяльності. 


\section{Література}

1. Бабкіна О. Проблема підвищення якості вищої освіти в Україні у контексті Болонських реформ / О. Бабкіна // Освіта і управління. -2006. - Т. 9, № 1.-С. 91 - 95.

2. Національна академія наук України: проблеми розвитку та входження в європейський науковий простір / за ред. О. С. Онищенка. - К., 2007.-680 с.

3. Самура І. Б. Методичні аспекти викладання фармакології іноземним студентам / І. Б. Самура // Актуальні питання фармацевтичної і медичної науки та практики. -2014. -№ 1. - С. $79-82$.

4. Шаповал М. І. Основи стандартизації, управління якістю і сертифікації: підручник / М. І. Шаповал. -К., 1997.$152 \mathrm{c}$.
5. Стандарт СТ МОЗУ 42-1.0:2005 “Фармацевтична продукція. Система стандартизації. Основні положення”.

6. Державна Фармакопея України / Державне підприємство "Науково-експертний фармакопейний центр". 1-е вид. - Харків : РІРЕГ, 2001.-556 с.

7. Технология и стандартизация лекарственных средств : в 2-х т. / под ред. В. П. Георгиевского и Ф. А. Конева. Харьков : ООО “РИРЕГ”, 1996.-Т. 1.-779 с. ; Т. 2. -783 с.

Отримано 20.05.14 